The Cryosphere, 2, 53-66, 2008

www.the-cryosphere.net/2/53/2008/

(c) Author(s) 2008. This work is distributed under

the Creative Commons Attribution 3.0 License.

\title{
Is snow sublimation important in the alpine water balance?
}

\author{
U. Strasser ${ }^{1}$, M. Bernhardt ${ }^{1}$, M. Weber ${ }^{2}$, G. E. Liston $^{3}$, and W. Mauser ${ }^{1}$ \\ ${ }^{1}$ Department of Geography, Ludwig-Maximilians University (LMU), Luisenstr. 37, 80333 Munich, Germany \\ ${ }^{2}$ Comm. for Glaciology, Bavarian Academy of Sciences and Humanities, Alfons-Goppel-Str. 11, 80539 Munich, Germany \\ ${ }^{3}$ Cooperative Institute for Research in the Atmosphere, Colorado State University, Fort Collins, Colorado 80523, USA
}

Received: 3 August 2007 - Published in The Cryosphere Discuss.: 6 September 2007

Revised: 25 April 2008 - Accepted: 25 April 2008 - Published: 23 May 2008

\begin{abstract}
In alpine terrain, snow sublimation represents an important component of the winter moisture budget, representing a proportion of precipitation which does not contribute to melt. To quantify its amount we analyze the spatial pattern of snow sublimation at the ground, from a canopy and from turbulent suspension during wind-induced snow transport for a high alpine area in the Berchtesgaden National Park (Germany), and we discuss the efficiency of these processes with respect to seasonal snowfall. Therefore, we utilized interpolated meteorological recordings from a network of automatic stations, and a distributed simulation framework comprising validated, physically based models. The applied simulation tools were: a detailed model for shortwave and longwave radiative fluxes, a mass and energy balance model for the ground snow cover, a model for the microclimatic conditions within a forest canopy and related snow-vegetation interactions including snow sublimation from the surface of the trees, and a model for the simulation of wind-induced snow transport and related sublimation from suspended snow particles. For each of the sublimation processes, mass rates were quantified and aggregated over an entire winter season. Sublimation from the ground and from most canopy types are spatially relatively homogeneous and sum up to about $100 \mathrm{~mm}$ of snow water equivalent (SWE) over the winter period. Accumulated seasonal sublimation due to turbulent suspension is small in the valley areas, but can locally, at very wind-exposed mountain ridges, add up to more than $1000 \mathrm{~mm}$ of SWE. The fraction of these sublimation losses of winter snowfall is between 10 and $90 \%$.
\end{abstract}

Correspondence to: U. Strasser

(u.strasser@iggf.geo.uni-muenchen.de)

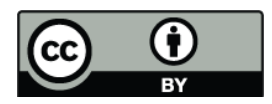

\section{Introduction}

Snow sublimation (the phase transition of water from solid to vapour) is a fundamental component of the alpine moisture budget. The total energy required is the sum of the latent heat of fusion (melting or freezing) and the latent heat of vaporization (evaporation or condensation), for a total of $2.838 \mathrm{~kJ} / \mathrm{kg}$ at $0^{\circ} \mathrm{C}$ and standard pressure. In this sum, the latent melting heat only represents $12 \%$ of the latent heat of vaporization. The energy and water exchange at the snowatmosphere interface is constrained by two important factors: the temperature of the (melting) snow surface cannot exceed $0^{\circ} \mathrm{C}$, and, consequently, the water vapour partial pressure at the surface will not exceed $6.11 \mathrm{hPa}$, limiting the humidity conditions at which evaporation can occur. Turbulent motion in the surface layer is driven mechanically by wind shear, and thermally by buoyancy over small-scale surface heterogeneities. Over snow, and in particular above inclined surfaces, the latter effect is typically not very significant. Due to the relatively large amount of energy required for sublimation, related snow mass change rates are generally assumed small compared with melting; however, for cold snow they can represent the only mass loss. In high mountain regions where the ridges are extremely wind-exposed and slopes are steep, accumulated solid precipitation is removed by the combined effects of sublimation, blowing-snow and avalanches. As a result, and in accordance with visual experience, the snowpack does not infinitely accumulate in areas where no melt occurs. Snow mass-balance models which do not include the latter effects underestimate ablation and lead to unrealistically high snow depths in long-term simulations.

Published by Copernicus Publications on behalf of the European Geosciences Union. 


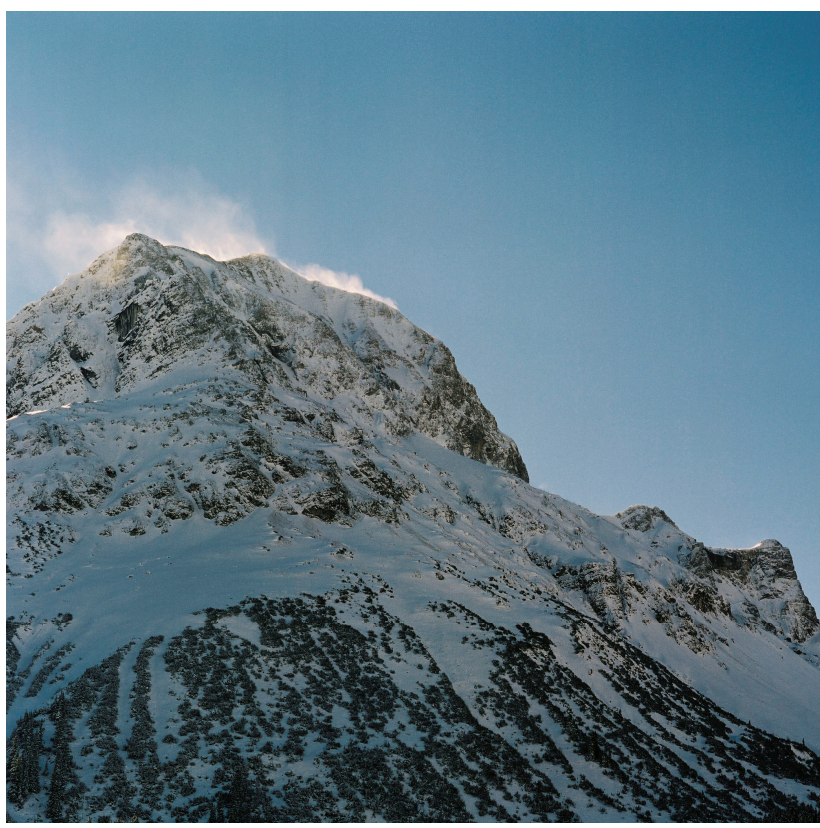

Fig. 1. Wind-induced snow plume on a mountain crest during blue skies (Photo: P. Neusser).

Much work has been invested in the study of snow sublimation processes and its important contribution to alpine water balances (Lang, 1981). At Niwot Ridge, Colorado Front Range, Hood et al. (1999) found $195 \mathrm{~mm}$ of water equivalent total net sublimation from the ground, or $15 \%$ of maximum snow accumulation, for the 1994-1995 snow season. The majority of this amount sublimated during the snow accumulation period, whereas $30 \mathrm{~mm}$ net resublimation to the snowpack occurred during the snowmelt period. The $15 \%$ total seasonal snow accumulation lost to sublimation compares well with earlier results, e.g. by Marks et al. (1992) or Kattelmann and Elder (1991). For Hintereisferner, an alpine glacier in the Ötztal Alps (Austria), annual mass losses due to snow and ice evaporation of approximately $100 \mathrm{~mm}$ have been measured with a lysimeter (Kaser, 1983).

In addition to latent fluxes from the ground, intercepted snow in a forest canopy can sublimate back into the atmosphere. Interception efficiency increases with the available deposition surface, increasing size of falling snow crystals, decreasing temperature, decreasing wind speed, and decreasing density of the falling snow (Pomeroy and Gray, 1995). Due to the large surface area to mass ratio, and the frequent high wind speeds in mountain forest canopies, an efficient turbulent exchange and thus sublimation process is enabled. The resulting proportion of snowfall which sublimates varies depending on interception efficiency, exposure time, and atmospheric conditions. Pomeroy et al. (1998) reported modelled seasonal intercepted snow sublimation to range from $13 \%$ of annual snowfall for a mixed spruce-aspen, $31 \%$ for mature pine and $40 \%$ for a mature spruce stand in the south- ern boreal forest of central Canada (Waskesiu Lake, Prince Albert National Park, Saskatchewan). Measurements of sublimation from intercepted snow within a subalpine forest canopy at a US continental site amounted to $20-30 \%$ of total snowfall accumulated at the site (Montesi et al., 2004).

In addition to interception and sublimation processes, micrometeorological conditions at the surface of a ground snow cover are modified by the existence of a forest canopy: shortwave radiation, precipitation and wind speed are reduced and the daily variations in the amplitude of temperature are decreased, whereas longwave radiation and humidity are more pronounced (Link and Marks, 1999; Tribbeck et al., 2004; Strasser and Etchevers, 2005). Consequently, latent fluxes and the associated sublimation rates at the snow surface inside a forest canopy differ from those in the open. The impact of snow interception on forest canopy optical properties and their implications for snowmelt modelling are discussed by Pomeroy and Dion (1996).

Finally, efficient exchange of energy and mass between the snow surface and the air masses above can occur during blowing-snow conditions (Pomeroy and Gray, 1995). By means of turbulent suspension the suspended snow crystals are mechanically decomposed and sublimate, the process being most efficient where fresh snow is available and the wind is accelerating, e.g. at ridges or narrow cols. In nature, sublimating snow from turbulent suspension can be observed as the snow plumes which are blown from high crests into the blue-sky atmosphere (Fig. 1), obviously revealing efficient removal of moisture from the near-surface layer of air. During snow storms sublimation may be limited due to higher saturation of the overlying air masses. A proper representation of the wind field is most relevant for an accurate simulation of wind-blown snow and the respective suspension and sublimation processes (Liston et al., 2007; Bernhardt et al., 2008a, $\mathrm{b}^{1}$ ). Although sublimation losses from turbulent suspension of wind-blown snow are limited in their spatial extent, they can locally reduce accumulated winter precipitation by a remarkable amount. Simulations of these effects result in significant portions of winter snowfall being sublimated, with the resulting moisture transport being important as both a source of water vapour to the atmosphere and in reducing the snow depth and snowmelt runoff in spring (Marsh, 1999).

Few models exist which simulate the full seasonal snow evolution including sublimation from the ground snow cover, from canopy-intercepted snow as well as blowing-snow redistribution processes (Burlando et al., 2002). An exception is SnowModel (Liston et al., 2007; Liston and Elder, 2006), which has been applied over a wide variety of blowing-snow environments. However, to our knowledge no investigation

\footnotetext{
${ }^{1}$ Bernhardt, M., Strasser, U., Liston, G. E., and Mauser, W.: High resolution modelling of snow transport in complex terrain using simulated wind fields, The Cryosphere Discuss., submitted, 2008b.
} 
has yet been conducted to include all relevant processes of snow sublimation for alpine areas by means of a distributed, continuous simulation, including lateral movement of snow slides which is a crucial prerequisite to realistically describe snow redistribution in areas with characteristic alpine orography. The goal of this study is to apply AMUNDSEN (Strasser et al., 2004, 2008), a modelling framework to simulate the energy and mass balance of a mountain snow cover, including coupled modules for forest snow processes (Liston and Elder, 2006) and snow slides (Gruber, 2007), together with SnowTran-3D (Liston and Sturm, 1998; Liston et al., 2007) to quantify the seasonal pattern of snow sublimation losses due to each of the specific processes, and identify their cumulative effect on the winter moisture budget at the scale of an alpine catchment $\left(210 \mathrm{~km}^{2}\right)$.

\section{Methods}

\subsection{Site description}

Berchtesgaden National Park is located in southeast Germany in Bavaria, at the southern corner of the administrative district Berchtesgadener Land (Fig. 2), and comprises an area of $210 \mathrm{~km}^{2}$ (http://www.nationalpark-berchtesgaden. de/). For the most part, the border of the National Park is represented by the national boundary to Austria. The moderate to high alpine area of the National Park includes the massifs Watzmann (2713 m a.s.1.) and Hochkalter (2606 m a.s.1.) as well as parts of the massifs Hoher Goell, Hagengebirge, Steinernes Meer and Reiter Alm. The mountain massifs are separated by the deep valleys stretching from south to north of the Koenigssee (water level $603 \mathrm{~m}$ a.s.l.), the Wimbach and the Klausbach. The valley areas are characterized by extensive forests with larch, spruce and mountain pine stands (Konnert, 2004). The mountains reach up to the nival zone.

The climate of the National Park area is subject to significant spatial variability, in response to the over 2000-m relief gradient. Small scale local differences are mainly caused by the general position in the mountainous landscape, the windward or lee position relative to the prevailing winds and solar exposure. Mean measured annual rainfall in the valleys is approximately $1500 \mathrm{~mm}$ with a July maximum.

\subsection{Data}

The input data required for the distributed modelling of snow processes consists of a digital elevation model (DEM, resolution $50 \mathrm{~m}$ ), the sky view factor (portion of the sky hemisphere which is visible at each location), hourly meteorological forcings of precipitation, global radiation, temperature, humidity, and wind speed, as well as the data characterizing the forest canopies in the area. Fields of simulated wind directions are derived using the Penn State University - National Center for Atmospheric Research MM5 model (Grell

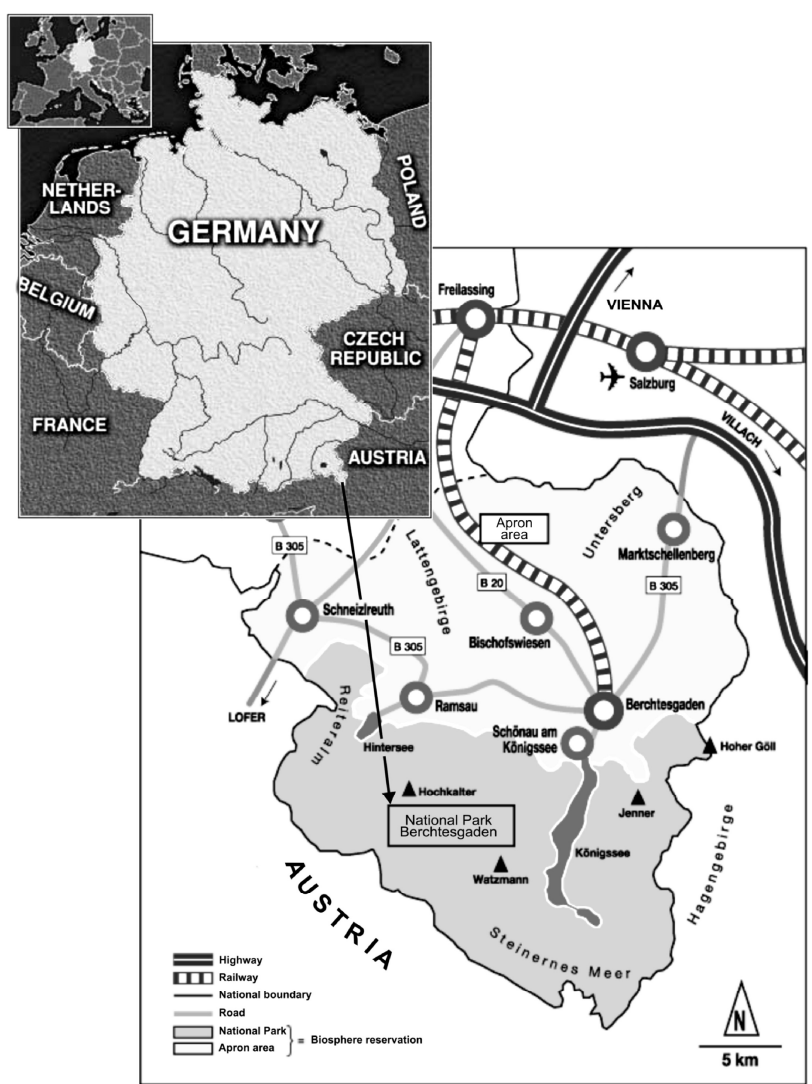

Fig. 2. Location of the Berchtesgaden National Park (Germany). The center (Watzmann) is located at 47.6 N/12.9 E.

et al., 1995) and downscaled with an energy-conserving procedure considering small-scale topography (Bernhardt et al., 2008a).

\subsubsection{Meteorological data}

The automatic network of meteorological stations located within the National Park are part of the operational infrastructure from the Bavarian avalanche warning service (LWZ) of the State Office for Environment (Jenner, Reiter Alm, Kuehroint, Funtenseetauern), the Administration of Salzburg (Untersberg) and the German Weather Service (DWD) (Schoenau). The meteorological stations are assembled according to the standards of the respective institutions (http://www.lawinenwarndienst-bayern.de/, http: //www.lwz-salzburg.org/station.asp?ID=9, http://www.dwd. $\mathrm{de} /$ ). Figure 3 shows the locations of the stations, and their position with respect to surrounding topography, e.g. the stations on the summits of Untersberg or Funtenseetauern ( $1776 \mathrm{~m}$ and $2445 \mathrm{~m}$ a.s.l., respectively). Table 1 gives an overview of the parameters recorded at each station. All data are aggregated to hourly means. For the study presented herein, we used the data from the annual period August 2003 to July 2004. 
Table 1. Altitude, location and set of recorded parameters with temporal resolution for the stations comprising the automatic network in the Berchtesgaden National Park. Coordinate system is UTM. The height of the sensors above the ground is between 3 and $8 \mathrm{~m}$. Accuracy of the recordings according to the technical specifications of the manufacturers is $0.3 \mathrm{~m} \mathrm{~s}^{-1}$ (wind speed), $\pm 0.3^{\circ} \mathrm{C}$ (temperature), $\pm 1 \%$ (humidity), $\pm 5 \%$ (global radiation) and $<0.4 \%$ (precipitation), respectively.

\begin{tabular}{lccclc}
\hline Station & Altitude [a.s.l.] & Easting [m] & Northing [m] & Parameters & Resolution \\
\hline Reiter Alm I & $1755 \mathrm{~m}$ & 4560494 & 5279436 & WS & $10 \mathrm{~min}$ \\
Reiter Alm II & $1670 \mathrm{~m}$ & 4560835 & 5279235 & T, H & $10 \mathrm{~min}$ \\
Reiter Alm III & $1615 \mathrm{~m}$ & 4560950 & 5278982 & T, H, GR, P & $10 \mathrm{~min}$ \\
Kuehroint & $1407 \mathrm{~m}$ & 4572314 & 5270625 & T, H, GR, WS, P & $10 \mathrm{~min}$ \\
Funtenseetauern & $2445 \mathrm{~m}$ & 4572939 & 5261755 & T, H, WS & $10 \mathrm{~min}$ \\
Jenner I & $1200 \mathrm{~m}$ & 4576659 & 5272417 & T, H & $10 \mathrm{~min}$ \\
Jenner II & $660 \mathrm{~m}$ & 4575000 & 5273988 & T, H, P & $15 \mathrm{~min}$ \\
Schoenau & $617 \mathrm{~m}$ & 4573987 & 5275597 & T, H, GR, WS, P & $10 \mathrm{~min}$ \\
Untersberg & $1776 \mathrm{~m}$ & 4575822 & 5287649 & T, H, WS, P & $30 \mathrm{~min}$ \\
\hline
\end{tabular}

$\mathrm{WS}=$ wind speed, $\mathrm{T}=$ air temperature, $\mathrm{H}=$ humidity, $\mathrm{GR}=$ global radiation, $\mathrm{P}=$ precipitation

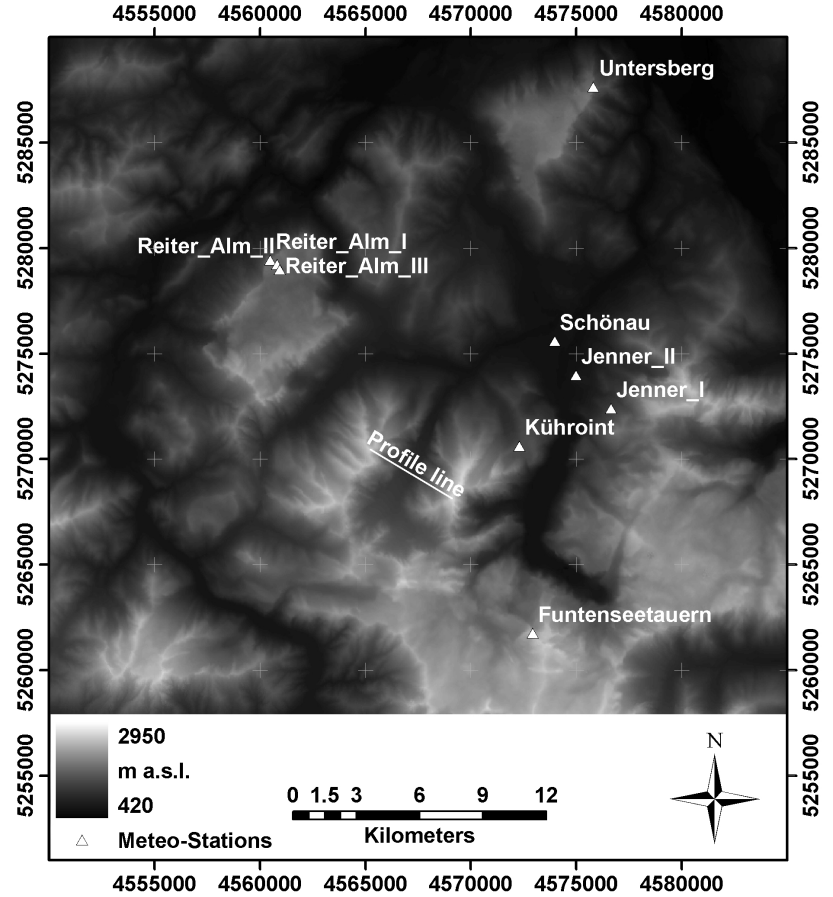

Fig. 3. Digital elevation model (DEM) for the National Park area and its surrounding, resolution $50 \mathrm{~m}$. The triangles represent the locations of the meteorological stations which comprise the automatic network. The straight profile line is a cross-section from the summit of Hochkalter (2607 m a.s.l.) to the one of Watzmann (2713 m a.s.1.).

Meteorological fields are provided hourly from the station recordings as follows: first, a so called gradient field is derived by linear regression of the meteorological observations with altitude; this regression is then applied for the entire area represented by the DEM within the altitudinal range in which the stations are located (above and below the gradient can be set to zero). Then, the residuals (i.e., the deviations of the measurements from the gradient field) are spatially interpolated by applying an inverse distance weighting (IDW) approach, resulting in a so called residual field representing the local deviations from the gradient field. The weights are the distances between a location represented by a DEM pixel and the stations. Relative humidity is converted to absolute humidity before spatial interpolation. In a last step, the gradient and residual fields are summed. This algorithm, applied for each time step, ensures that the station observations are reproduced, and it can be applied irrespective of whether a relation of the meteorological variable with altitude or local deviations exist. We are aware that with this procedure we cannot consider all energy exchange processes in the area between the stations and the uncertainty in spatially interpolating the measurements in the area of our investigation might be a magnitude larger than the one inherent in the measurements themselves. However, we trust in its applicability during the snow season in which at least the surface is mostly covered by snow and therefore the representativeness of the recordings is high. Since we are interpreting seasonal totals, many of the errors might also compensate for each other.

\subsubsection{Forest canopy data}

For the simulation of canopy interception processes, data fields of leaf area index (LAI) and canopy height are required as model inputs. In the National Park area, these datasets have been derived from a combination of forest inventory data, a color infrared aerial photograph interpretation, and by application of the relations by Hammel and Kennel (2001). For snow cover modelling, an effective LAI including stems, leaves, and branches (Chen et al., 1997) is required. To account for that, values for the cortex area index are added. During winter, vegetation is not active; minimum LAI values for the winter season have therefore been derived by 

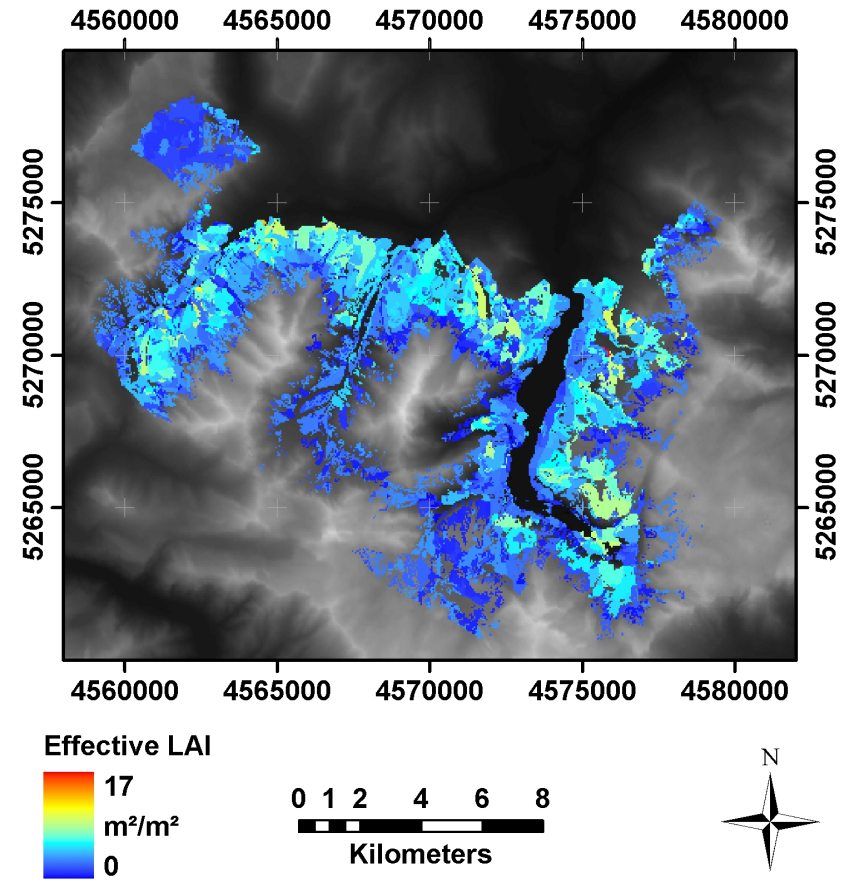

Fig. 4. Effective winter leaf area index for the forest canopies within the National Park area. Canopy data is only available for the National Park central area.

multiplying the values for spruce (picea abies) with a factor of 0.8 , and the one for pine (pinus cembra) with 0.6 ; for the mountain pine shrubs (pinus mungo) LAI is assumed to be 3.2 (V. Konnert, personal communication, 2006.). Resulting effective winter LAI and canopy height are illustrated in Figs. 4 and 5, respectively.

\subsection{Models}

\subsubsection{Ground snow processes}

The Alpine MUltiscale Numerical Distributed Simulation ENgine AMUNDSEN (Strasser et al., 2004, 2008) is a simulation framework for continuous, distributed modelling of snow processes in high mountain areas. In the current version, the functionality of AMUNDSEN includes rapid computation of topographic parameters from a digital elevation model, several interpolation routines for scattered meteorological measurements (Strasser et al., 2004), simulation of shortwave and longwave radiative fluxes including consideration of shadows and cloudiness (Corripio, 2003; Greuell et al., 1997), parameterization of snow albedo (US Army Corps of Engineers, 1956; Rohrer, 1992), modelling of snowmelt with either an energy balance model (Strasser et al., 2008) or an enhanced temperature index model considering radiation and albedo (Pellicciotti et al., 2005), modelling of forest snow processes (Liston and Elder, 2006), as well as simulation of snow slides from steep mountain slopes along couloir

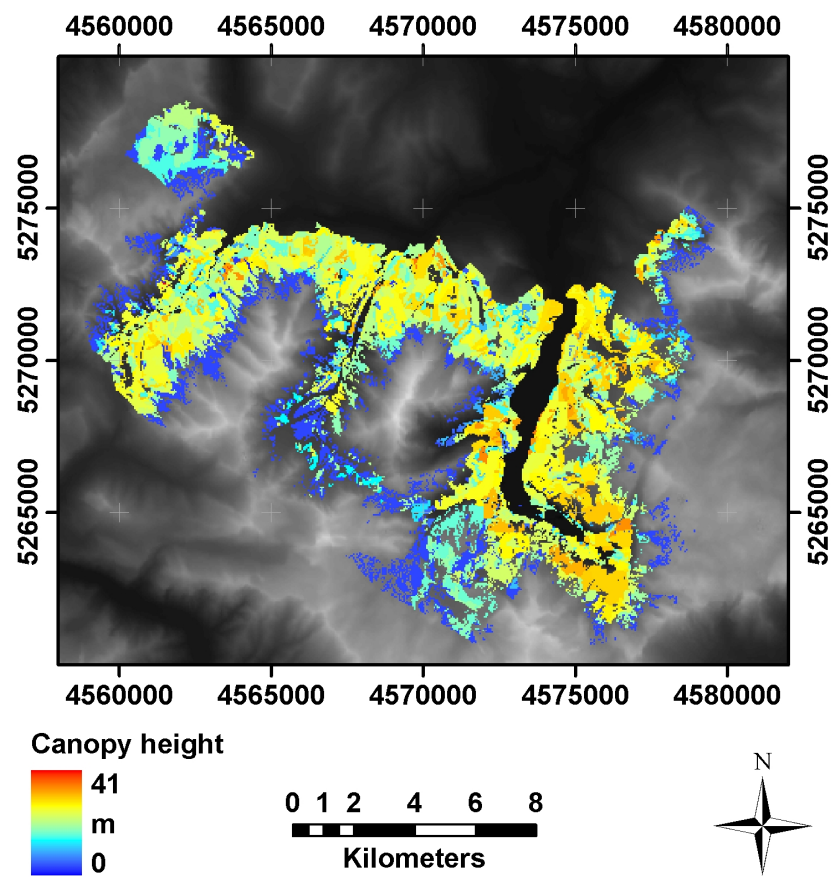

Fig. 5. Canopy height for the forest canopies within the National Park area. Canopy data is only available for the National Park central area.

courses which are derived from the DEM (Gruber, 2007). The latter is required to remove snow from areas where it would otherwise infinitely accumulate in long-term simulations. The time step for the snow slide module is set to once a day. Finally, a built-in stochastic weather generator can be used to produce synthetic future meteorological data for climate change scenario simulations of any length (Strasser et al., 2008).

Of specific importance for snow modelling in mountainous regions is the calculation of the shortwave radiative fluxes, significant local differences being caused by several elevation dependent atmospheric processes and the effect of topography. In AMUNDSEN, they are quantified by means of a parameterization scheme which considers the effects of hill shading, the decrease of atmospheric transmittance due to the individual processes of scattering, multiple reflections between the atmosphere and the ground, as well as reflections from surrounding terrain. Atmospheric longwave radiative fluxes are computed using the formula of Greuell et al. (1997), based on a virtual longwave emissivity of the atmosphere which depends on temperature, humidity and cloudiness. The latter is derived by comparison of potential global radiation with the recordings. In addition, longwave thermal radiation from surrounding slopes are considered, thereby accounting for whether these slopes are snow covered or not.

The physically based snow cover module in AMUNDSEN is designed to simulate the surface energy balance, water 
equivalent, and melt rate of snow in the domain. In each time step the following scheme is followed: first, it distinguishes between areas with melting conditions (air temperature $\geq 273.16 \mathrm{~K}$ ), and areas with no melt (air temperature $<273.16 \mathrm{~K})$. For the first case, the computations include: (a) calculation of the radiation balance, (b) calculation of the turbulent fluxes including mass changes by sublimation/resublimation, (c) decision whether eventual precipitation is solid or liquid (if not measured), and calculation of the respective advective heat flux, (d) calculation of snowmelt, if the resulting surface energy balance is positive, and (e) update of the mass budget. For the other areas (air temperature $<273.16 \mathrm{~K}$ ), an iterative procedure is used to determine the snow surface temperature required to satisfy the surface energy balance. For physical descriptions of the turbulent fluxes, detailed measurements of the snow surface properties are required. Therefore, AMUNDSEN incorporates a common empirical description valid for the (most frequent) conditions of medium roughness, stable stratification and a wide range of wind speeds. The latent heat flux $V$ (in $\mathrm{W} / \mathrm{m}^{2}$ ) is calculated using the formula proposed by Kuchment and Gelfan (1996):

$V=32.82 \cdot(0.18+0.098 \cdot W) \cdot\left(e_{l}-e_{s}\right)$

where $W$ is the measured wind speed $(\mathrm{m} / \mathrm{s}), e_{l}$ is the water vapour partial pressure at measurement level and $e_{s}$ the water vapour saturation pressure at the snow surface, with both water vapour pressures being calculated using the Magnus formula and expressed in $\mathrm{hPa}$. This formula is one example out of the many available empirically derived bulk formulas that depend on mean wind speed recorded at a single height (usually $2 \mathrm{~m}$ ). The small mass changes $\delta e(\mathrm{~mm})$ generated by sublimation or resublimation to surface hoar are then simulated with

$\delta e=\frac{V \cdot d t}{l_{s}}$

where $l_{s}$ is the sublimation/resublimation heat of snow $(2.838 \mathrm{~kJ} / \mathrm{kg})$ and $d t$ the duration between two modelling time steps (here $3600 \mathrm{~s}$ ). With a positive latent flux (towards the snow surface), mass is gained with resublimation, whereas with a negative latent flux (away from the surface), mass is lost due to sublimation. Equations (1) and (2) provide a robust approach to calculate the mass flux towards and away from the ground snow surface that is appropriate for the scale considered here and only requires minimal input data.

The algorithm used to simulate snow sliding down steep mountain slopes is a mass-conserving, multiple flow directions procedure which propagates the snow masses along predefined flow couloirs (Gruber, 2007). At decreasing slope angle, the snow is deposited. As a result, snow is removed from the steep rock faces and accumulated at the foot of the hill slopes in the valleys.

\subsubsection{Canopy interception and sublimation}

Processes affecting snow cover beneath a forest canopy are different from those in the open: on one hand, the meteorological parameters for simulating the evolution of the snow beneath the canopy are different, and on the other hand, a certain amount of precipitation is retained as interception storage. From there, it can melt and fall down to the ground, or sublimate into the air masses above the canopy. This latter process leads to a reduction of precipitation accumulated and stored in the ground snowpack. A forest canopy can lead to both less SWE and shorter duration, or more SWE and longer duration of the snow cover beneath the trees, depending on many factors such as canopy density, gap size and distribution, geographic location and meteorological conditions (Pomeroy et al., 2002). In AMUNDSEN, the processes of interception, unloading by melt and fall down to the ground, as well as sublimation are calculated depending on canopy height and effective LAI, using two well-documented parameterizations from the literature, mostly following the scheme of Liston and Elder (2006) which is based on the work of Pomeroy et al. (1998). The mass loss rate $d m / d t$ from an ice sphere (in $\mathrm{kg}$ ), given by the combined effects of humidity gradients between the particle and the atmosphere, absorbed solar radiation, particle size and ventilation influences, is computed with:

$$
\frac{d m}{d t}=\frac{2 \cdot \pi \cdot r \cdot\left(\frac{H}{100}-1\right)-S_{a} \cdot \Omega}{l_{s} \cdot \Omega+\frac{1}{D \cdot \rho_{v} \cdot S_{h}}}
$$

with $m(\mathrm{~kg})$ being the particle mass, $r$ the radius, $H$ the measured relative humidity in $\%, S_{a}\left(\mathrm{~W} / \mathrm{m}^{2}\right)$ the solar radiation absorbed by the ice particle, $\rho_{v}$ the water vapor density at saturation $\left(\mathrm{kg} / \mathrm{m}^{3}\right), S_{h}$ the Sherwood number and $D$ the diffusivity of water vapor in the atmosphere $\left(\mathrm{m}^{2} / \mathrm{s}\right)$ at air temperature $T . \Omega$ is a term describing ventilation efficiency.

In addition to mass lost by sublimation, snow can melt and be unloaded through falling down to the ground. For air temperatures above freezing, we assume a daily unloading rate of $5 \mathrm{~kg} /\left(\mathrm{m}^{2} \mathrm{~d} \mathrm{~K}\right)$ for both the combined effects of melt and falling down of snow to the ground (Liston and Elder, 2006). The resulting unloaded mass is added to the solid precipitation reaching the ground beneath the trees. There, the energy balance is computed as for the open, but using meteorological parameters modified for forest conditions: precipitation is reduced by the amount of snow that has been intercepted in the canopy, wind speed is reduced applying a relationship by Cionco (1978) considering canopy height, humidity is increased (Durot, 1999), and, finally, reference level temperature attenuation is simulated after Obled (1971).

\subsubsection{Wind-induced snow transport}

For the simulation of wind-induced snow transport and the related snow sublimation losses originating from turbulent suspension we used SnowTran-3D (Liston and Sturm, 1998; 
Liston et al., 2007). SnowTran-3D is a three dimensional, physically based model which simulates snow-depth evolution resulting from wind-blown snow. The model was originally developed and validated in the arctic tundra of Alaska but has since its introduction been applied in a wide range of landscapes (Green et al., 1999; Liston et al., 2000; Prasad et al., 2001; Hiemstra et al., 2002; Liston and Sturm, 2002; Hasholt et al., 2003; Bruland et al., 2004; Hiemstra et al., 2006). Recently, the use of modelled wind fields has allowed to apply and validate the model in the high mountain area of the Berchtesgaden National Park (Bernhardt et al., 2008a, $b^{1}$ ). The main component of SnowTran-3D include a) the wind forcing field (here replaced by the Bernhardt et al. (2008a) modelled wind fields), the wind shear stress at the surface, the transport of snow by turbulent suspension, the sublimation of suspended snow, and the accumulation and erosion of snow (Liston and Sturm, 1998). The model's formulation for the sublimation rate of windtransported snow follows that of Pomeroy et al. (1993) and Pomeroy and Gray (1995). The sublimation rate of transported snow $Q_{v}\left(\mathrm{~kg} /\left(\mathrm{m}^{2} \mathrm{~s}\right)\right)$, per unit area of snow cover, is given with $x *(\mathrm{~m})$ being the horizontal coordinate in a reference frame defined by the wind-flow direction (increasing down-wind):

$Q_{v}\left(x^{*}\right)=\Psi_{S} \Phi_{S} h_{*}+\int_{h_{*}}^{z_{t}} \Psi_{t}\left(x^{*}, z\right) \Phi_{t}\left(x^{*}, z\right) d z$

where $\Psi(1 / \mathrm{s})$ is the sublimation loss-rate coefficient and $\Phi$ $\left(\mathrm{kg} / \mathrm{m}^{3}\right)$ is the vertical mass-concentration distribution. The integration limits range from the snow surface through the saltating and turbulent-transport regimes (Liston and Sturm, 1998). The subscripts $S$ and $t$ represent saltation ( $z=0$ to $z=h_{*}$, the height of the saltation layer) and turbulent suspension layers, respectively.

The sublimation loss rate coefficient, describing the rate of particle mass loss as a function of height within the drifting snow profile, is a function of temperature-dependent humidity gradients between the snow particle and the atmosphere, conductive as well as advective energy and moisture transfer mechanisms, particle size and solar radiation intercepted by the particle. Thereby, the time rate of mass loss from an ice sphere is calculated based on the same principles as given in Eq. (3). It is assumed that (a) the mean particle size decays exponentially with height, (b) the relative humidity follows a logarithmic vertical profile, (c) the air temperature in the snow-transport layer is well mixed and constant with height, (d) the variables defined within the saltation layer are constant with height and those in the turbulent suspension layer vary with height, and (e) the solar radiation absorbed by snow particles is a function of the solar elevation angle and fractional cloud cover. The details of this formulation are given by Liston and Sturm (1998); the specific setting of the model as adopted to our domain is described in Bernhardt et al. $(2008 b)^{1}$.

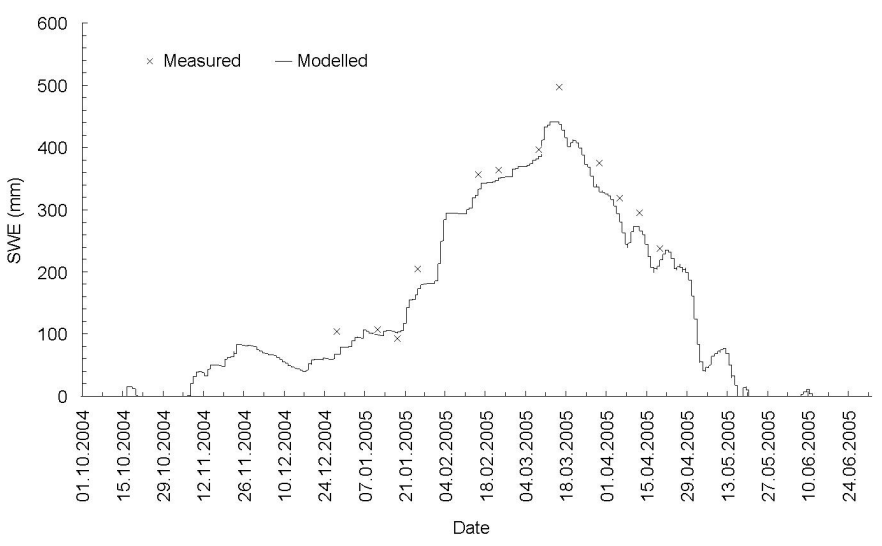

Fig. 6. Measured and modelled seasonal course of snow water equivalent at Kuehroint (1407 m a.s.1.), winter season 2004/05 (no validation data available before). Mean deviation: $26.6 \mathrm{~mm}$.

Using SnowTran-3D, $15-50 \%$ of the snow cover were found to be returned to the atmosphere by sublimation in the Arctic (e.g., Liston and Sturm, 1998; Essery and Pomeroy, 1999; Pomeroy and Essery, 1999), or 15-41\% in the Canadian prairies (Pomeroy and Gray, 1995).

\subsection{Validation}

Concerning validation of the effects considered here, we rely on models which have been validated elsewhere and proved to deliver robust results compared to local measurements. In particular, the modelling of the ground snow cover as implemented here has been compared with measurements by several investigators (Strasser et al., 2002; Zappa et al., 2003), including analyses at the regional scale using satellite-data derived snow cover (Strasser and Mauser, 2001; Prasch et al., 2007). As an example, comparison of modelled SWE with snow pit measurements is illustrated in Fig. 6 for the Kuehroint station site. The snow interception model has been validated by Montesi et al. (2004) using observations from a continental climate site located within the US Department of Agriculture (USDA) Fraser Experimental Forest $\left(39^{\circ} 53^{\prime} \mathrm{N}, 105^{\circ} 54^{\prime} \mathrm{W}\right)$ near Fraser, Colorado, USA. The results achieved here are also in agreement with the ones collected by Suzuki and Nakai (2008) for various sites in different climates. The inside-canopy modification of meteorological parameters has been measured, and the respective parameterization derived, by Durot (1999) for the Col de Porte observation site (1420 m a.s.l.) in the French Alps. The snow slides module has been set up and parameterized with data from the Pizzac Avalanche in the Italian Alps (Sovilla, 2004) by Gruber (2007). Finally, SnowTran-3D has been validated at a vide variety of landscapes, including Colorado, Antarctica, Idaho, Wyoming/USA, Alaska, Greenland, Svalbard/Norway and Siberia (complete references are given in Liston et al., 2007). Bernhardt et al. (2008b) $)^{1}$ validated the 


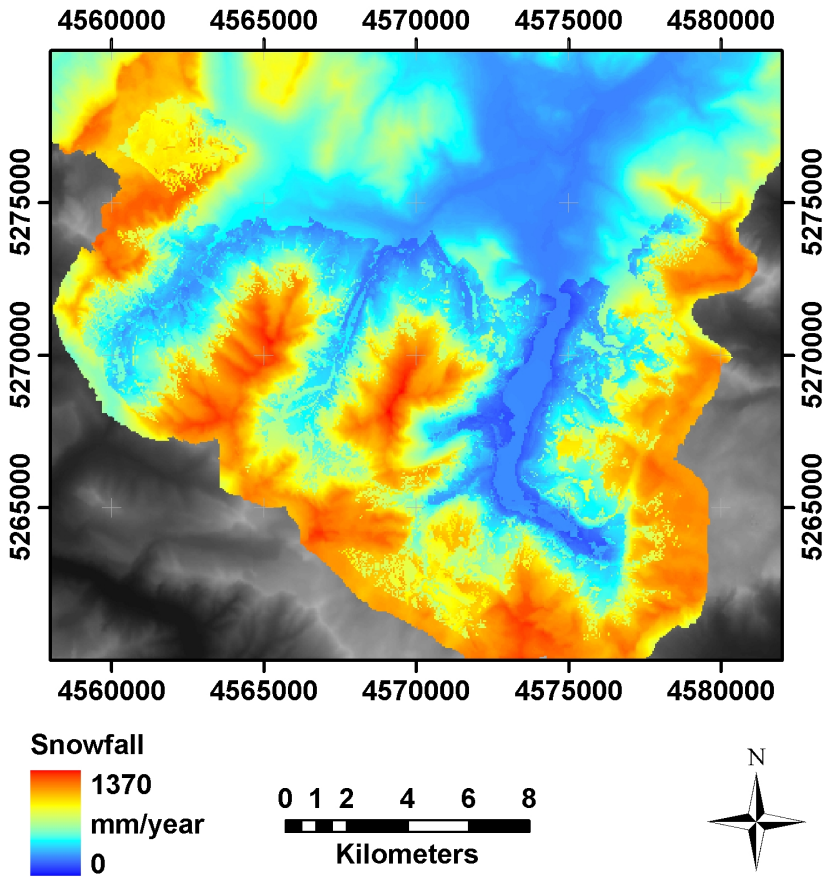

Fig. 7. Annual snowfall (solid precipitation) for the National Park area, 1 August 2003 to 31 July 2004.

model in the domain investigated here with stake readings from snow erosion and deposition zones.

A distributed measurement of the combined effects of snow sublimation from the ground, from the canopy and from wind-induced snow transport is not possible. Therefor we follow the strategy to estimate and compare the effects of snow sublimation processes as simulated with models (which have been validated at the point scale already) for an entire winter season at the catchment scale in an alpine domain. This provides us a picture of the effects which can then be discussed with respect to the relevance of the single processes for the annual water balance.

\section{Results and discussion}

In the following, we describe the results of the AMUNDSEN and SnowTran-3D simulations for the year August 2003 to July 2004; all values in $\mathrm{mm}$ are related to that period. The winter season (November to April) was characterized (in mid altitudes) by several snow falls without a continuous snow cover until December, then accumulation of a high winter snow cover, interrupted with single but only slight melting events, and then a relatively fast and straightforward melt from March until the end of April.

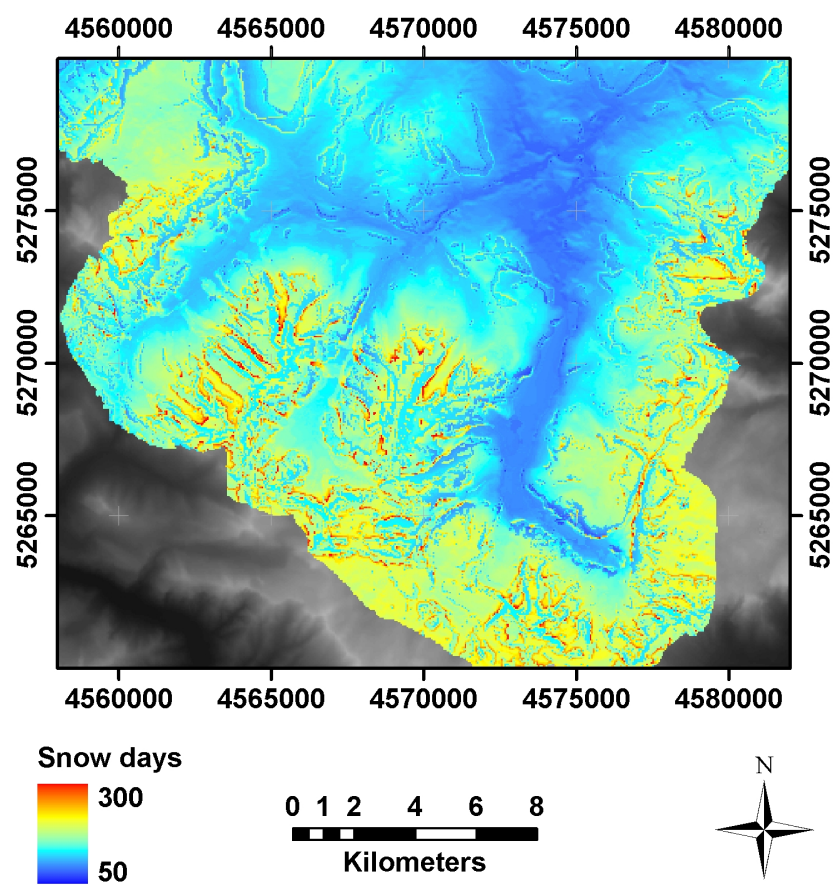

Fig. 8. Snow cover duration for the National Park area, 1 August 2003 to 31 July 2004.

\subsection{Snowfall distribution}

For distinguishing between rain and snow, the precipitation and temperature fields were combined, and $1{ }^{\circ} \mathrm{C}$ was set to be the phase transition threshold temperature. For the discussion here, snowfall is defined as that portion of solid precipitation which is actually deposited at the ground. Hence, it is not modified by the snow that is intercepted in the trees of the canopy. In Fig. 7, the derived hourly snowfall fields are accumulated to provide a picture of seasonal snowfall distribution: generally, snow precipitation increases with height with a maximum of almost $1400 \mathrm{~mm}$ in the summit regions of the highest mountains. In the valleys, accumulated seasonal snowfall is approximately $250 \mathrm{~mm}$. Where forest covers the mountain slopes, annual snowfall reaching the ground is between $300 \mathrm{~mm}$ and $800 \mathrm{~mm}$. Due to sublimation losses of snow intercepted in the canopy, the mountain forests appear as a sharply delineated minimum area. The accumulated snowfall visualized in Fig. 7 is the amount of snow available for spring melt, apart from the little modifications of the ground snow mass balance generated by the sublimation and resublimation processes discussed in the following.

The number of days with snow coverage (Fig. 8) ranges from less than 100 in the valley areas and more than 200 on the higher plateaus like the Untersberg (upper right). A local, but significant modification of this range is caused by the modelled snow slides: in the source areas, snow cover duration is found to be less than 70 days (e.g. the very steep slopes surrounding the southern waterside of the Koenigssee, 

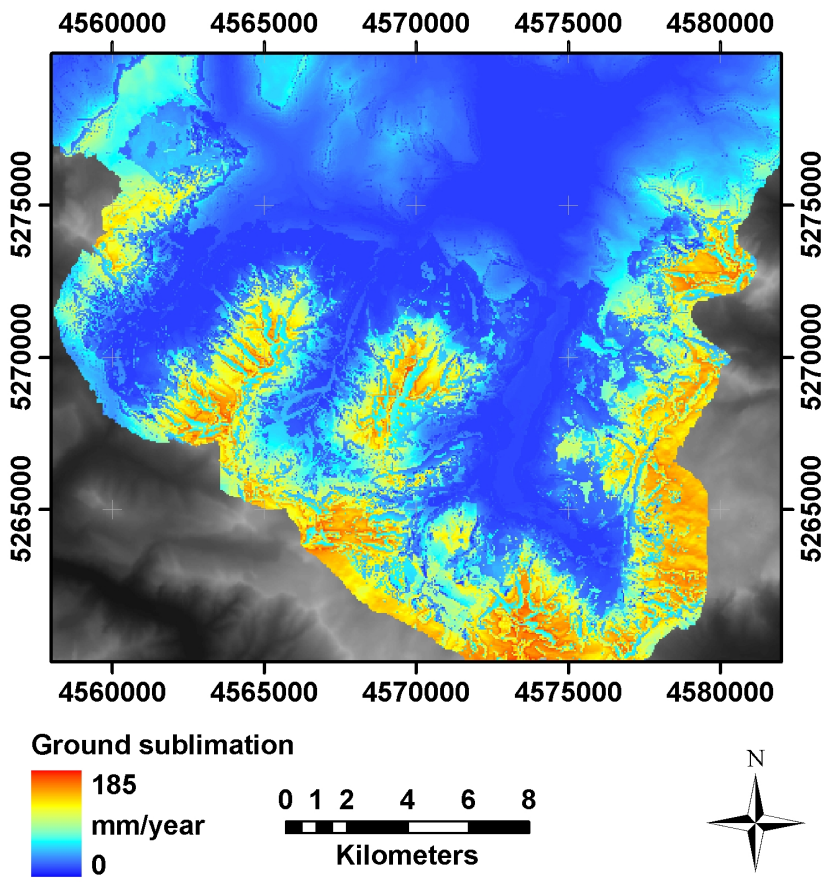

Fig. 9. Modelled total winterly snow sublimation losses from the snow surface in the National Park area (2003/2004).

or the northwestern edge of the Lattengebirge in the north of the Park area). On the other hand, some accumulation areas in the valleys remain snow-covered for more than 300 days (at the run-out zones of the couloir gullies at the foot of steep mountain slopes). Consequently, some of these regions coincide with the locations of the existing glaciers (Blaueisgletscher and Watzmanngletscher).

\subsection{Ground snow sublimation and resublimation}

The processes of sublimation and resublimation at an exposed snow surface are associated with simultaneous adjustment of both the thermal energy and the water content of the affected snow layer. According to our previous considerations, mechanically induced turbulence is the main mechanism for the transport of latent heat between the surface and the atmosphere. Its efficiency depends on the irregular and chaotic small scale motion in the surface layer air flow. Generally, one prerequisite for sublimation is a negative saturation deficit, and available energy for the phase transition. At night, sublimation can therefore occur only under very dry and warm conditions with stable stratification, usually within katabatic flow layers, when the sensible heat flux compensates for longwave emission (usually in the range of 0 to $\left.-70 \mathrm{~W} / \mathrm{m}^{2}\right)$.

For the purpose considered here, the latent heat flux can be parameterized using empirically derived bulk formulas of the type of Eq. (1). Such are based on flux-variancerelationships and assuming kinematic latent fluxes can be

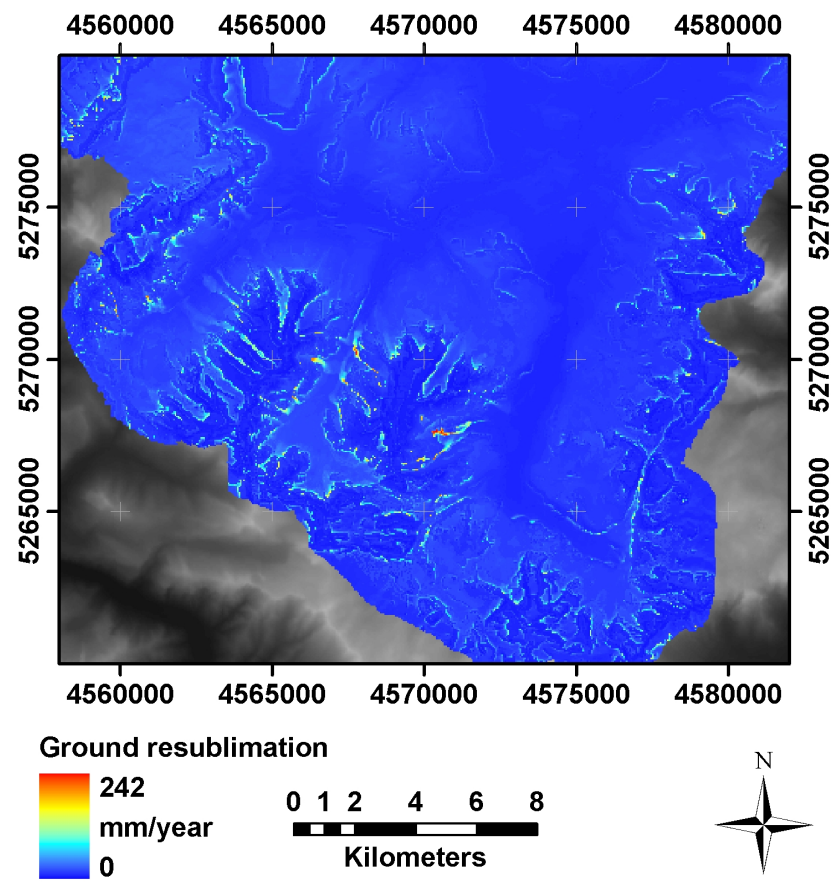

Fig. 10. Modelled total winterly snow yield by resublimation to the snow surface in the National Park area (2003/2004).

calculated from the product of variances of vertical wind speed and water vapour (Foken, 2003); the variances are estimated using mean horizontal wind speeds and water vapour differences (Weber, 2007). Utilizing this approach together with Eq. (2), the mass flux form the snow surface to the atmosphere or vice versa were hourly computed. Resublimation was only considered if snow is present at the ground. Required inputs of wind speed and relative humidity at each time step were provided using the same spatial distribution procedure as used for the other meteorological variables (see Sect. 2.2.1). Resulting rates of sublimation mass loss and resublimation mass gain are considered in the hourly modelling of the mass balance of the snow cover. Figures 9 and 10 show the accumulated seasonal patterns of sublimation and resublimation at the ground surface for the National Park area.

Minimum ground snow sublimation of only a few $\mathrm{mm}$ was simulated for the valley areas where the snow cover duration was short, wind speeds were low and turbulent mixing at the snow surface was limited (snow cover duration is illustrated in Fig. 8). At higher elevations, sublimation losses generally increase, with maxima of approximately $180 \mathrm{~mm}$ occurring in the summit regions. Highest sublimation occurs at locations where snow is exposed to relatively high wind speeds (e.g., on the summit crests of Hochkalter and Watzmann, the start and end points of the profile transect in Fig. 3). Forest canopy areas represent local minima for ground snow sublimation $(10 \mathrm{~mm}$ to $30 \mathrm{~mm})$. In these areas not only the amount of snow reaching the ground is reduced, but also incoming radiation and wind speed are less, and humidity is higher than 


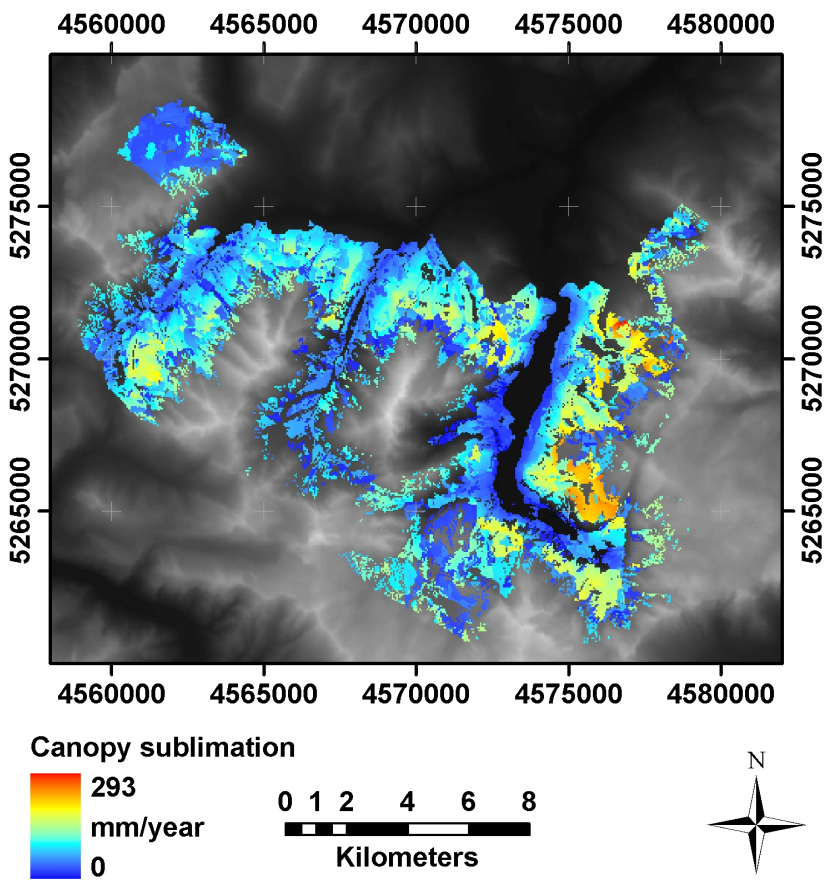

Fig. 11. Modelled total winterly snow sublimation from the canopies in the National Park area (2003/2004).

in the open. Couloirs and very steep slopes where most of the snow is removed by snow slides are also areas of comparably low seasonal sublimation amount, results are in the range of $50 \mathrm{~mm}$. Steep rock faces are represented as bright bands around the mountain plateau massifs (e.g., Reiter Alm or Untersberg), here the snow that has slided down accumulates and often remains until late spring. The ground resublimation picture (Fig. 10) reveals small values of $10 \mathrm{~mm}$ to $20 \mathrm{~mm}$ in the most areas. High maximum values of more than $200 \mathrm{~mm}$ can be found in the small snow deposition zones where the snow slides are retained and accumulate: here, the snow covered period lasts until summer (see Fig. 8), and consequently, frequent warm air and high water vapour pressure conditions in the surface layer enable an efficient latent flux towards the snow surface.

\subsection{Canopy snow sublimation}

In general, sublimation of snow intercepted in the trees of a mountain canopy increases with (a) larger LAI, (b) higher air temperature, (c) more incoming solar radiation, (d) less atmospheric moisture, and (e) higher wind speed and thus more efficient turbulent mixing, at least up to a certain wind speed threshold. In Fig. 11 the sublimation rates have been accumulated to a seasonal total of sublimation SWE loss for the National Park canopies. Resulting total sublimation ranges between approximately $30 \mathrm{~mm}$ (mountain pine stand at the Reiter Alm) and typically around $200 \mathrm{~mm}$ for the $30 \mathrm{~m}$ and higher spruce stands east of the Koenigssee.

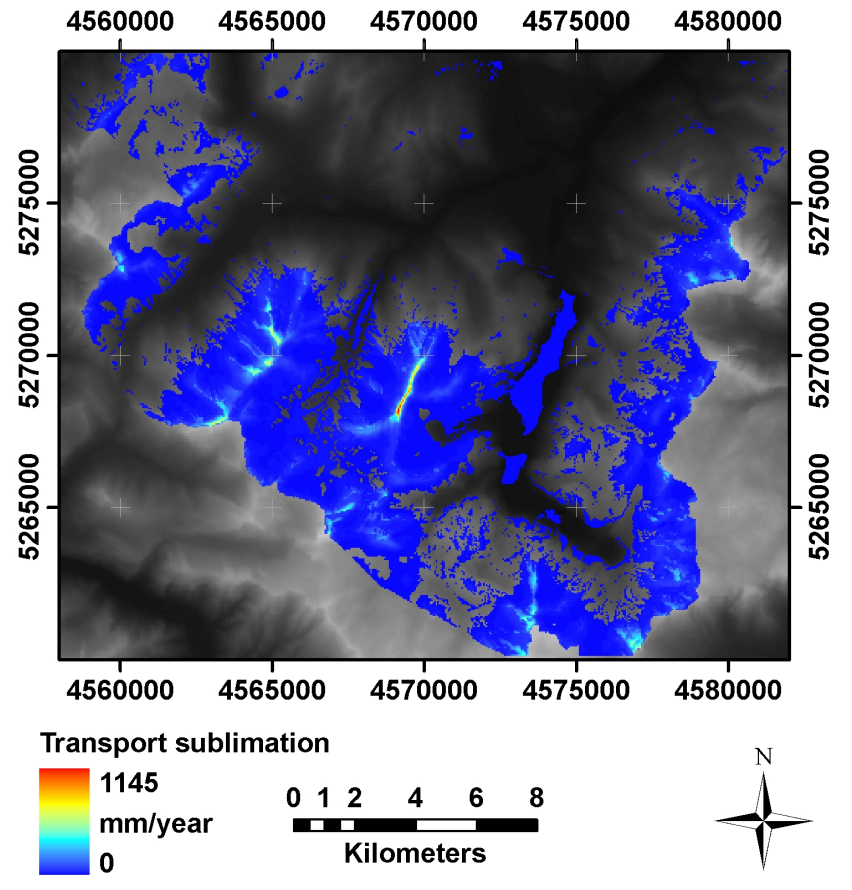

Fig. 12. Modelled total winterly snow sublimation from windinduced snow transport in the turbulent suspension layer in the $\mathrm{Na}-$ tional Park area (2003/2004).

Maximum values of more than $250 \mathrm{~mm}$ can be found for very dense stands in well ventilated, south-exposed slopes. Generally, frequent smaller snowfall events during winter result in higher total sublimation amount than do intensive but singular events, since the interception storage is limited and hence precipitation surplus falls to the ground. Hence, it is the frequency and duration of snow undergoing the interception processes that governs total sublimation amount. Snow that does not sublimate and therefore remains within the interception storage can melt and fall down to the ground later; this process is computed with a temperature-index model following Pellicciotti et al. (2005).

\subsection{Sublimation of snow from turbulent suspension}

For the simulations of total winter snow sublimation losses due to wind-induced snow transport discussed here, SnowTran-3D was run with the same DEM and meteorological forcing as AMUNDSEN. Only wind speed and direction data were provided using a library of local wind fields simulated with the Penn State University - National Center for Atmospheric Research MM5 model (Grell et al., 1995), applying the procedure described in Bernhardt et al. (2008a). The efficiency of the sublimation process during blowingsnow events depends on the amount of snow in the simulated layers of saltation and turbulent suspension. Accumulated blowing-snow sublimation rates for winter 2003/2004 are illustrated in Fig. 12. Although the areas of significant 


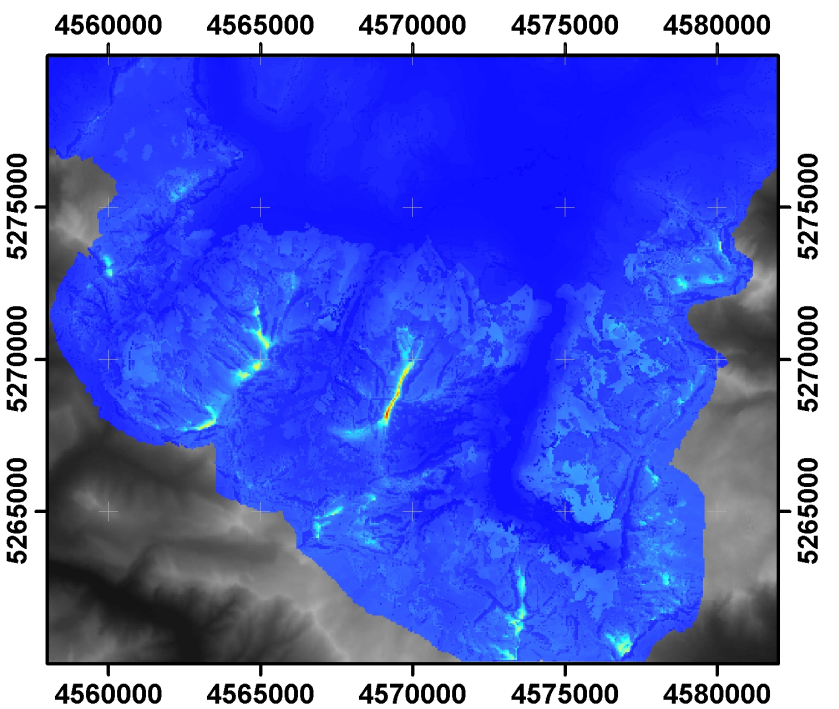

Total sublimation

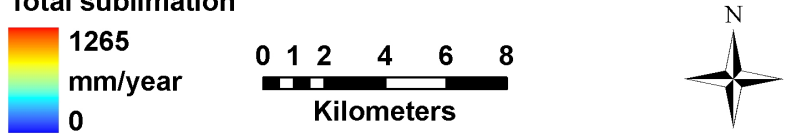

Fig. 13. Modelled total winterly snow sublimation from the ground, the canopies and from wind-induced snow transport in the turbulent suspension layer in the National Park area (2003/2004).

sublimation losses due to turbulent suspension are spatially limited (below $1800 \mathrm{~m}$ a.s.l. they are negligibly small), the effect is very significant at the local (pixel) scale: at the summit crests and ridges of the mountain massifs of Hochkalter and Watzmann, more than $1000 \mathrm{~mm}$ of SWE are modelled to sublimate into the atmosphere. At such wind-exposed locations with frequent occurrence of high wind speeds the processes of snow entrainment and transport are very efficient, and so is moisture transport across the top of the boundary layer in the air masses above.

\subsection{Distribution of total snow sublimation}

Total snow sublimation losses from the winter snow cover is given by the sum of the three described processes (Fig. 13). Sublimation from the ground and the canopy interception storage are similar in their seasonal efficiency and represent a total loss of approximately $100 \mathrm{~mm}$ of SWE over quite extensive areas in our test site. Only in a small, but exceptionally dense spruce stand east of the Koenigssee almost $300 \mathrm{~mm}$ of SWE sublimates from the canopy due to the high effective LAI there (see Fig. 4). The general shape of the ground sublimation profile is driven by the exponential expression of the water vapour calculation required for solving Eq. (1). Sharp edges result from the snow slide erosion/deposition areas where the melt out is distinctly different from that in the other regions in the same altitude. Minima can result from south-exposed areas where the melt out is earlier, from areas

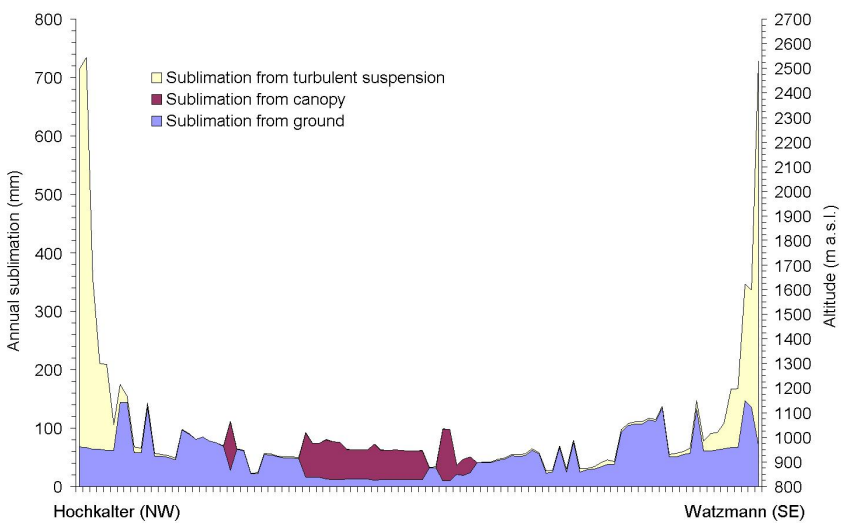

Fig. 14. Simulated contributions to annual snow sublimation from the ground, canopy intercepted snow and wind-induced, turbulent suspended snow along a cross-section from Hochkalter (2607 $\mathrm{m}$ a.s.1.) through the Wimbachtal to Watzmann (2713 $\mathrm{m}$ a.s.1.) (see also Fig. 3).

where snow is laterally removed, or from beneath trees where less snow is accumulated at the ground. Sublimation of snow from turbulent suspension during blowing-snow events is generally much more efficient, but very limited in its local extent. In Fig. 14, all modelled sublimation losses are illustrated for a profile transect from Hochkalter (2607 m a.s.1.) across the Wimbach valley to the Watzmann (2713 m a.s.1.), both summits being prominent culmination points. At both sides of the profile transect, sublimation rates increase significantly due to the contribution from turbulent suspension during wind-induced snow transport. In the spatial representation (Fig. 15) this effect is dominant over the other two: the wind-exposed mountain crests appear as maximum areas with total sublimation amount of up to $1200 \mathrm{~mm}$. Dividing this picture by the seasonal snowfall distribution (Fig. 7) results in the fraction of sublimation losses from total seasonal snowfall precipitation as shown in Fig. 15. This fraction amounts to 10 to $20 \%$ in large valley areas and on mountain slopes, up to $50 \%$ in the denser canopy stands, and up to $90 \%$ at the highest mountain crests.

Finally, it is possible to determine the relative contribution of the simulated components of the winter water balance computed as mean quantities over the domain (Table 2). Snowmelt is by far the dominant element (more than snowfall, despite the different losses, due to rain-on-snow), while the contribution of the ground and wind-induced transport sublimation fluxes is small (6.9 and $4.1 \%$, respectively). Sublimation from snow previously intercepted in the canopy can be classified as moderate (13.9\%), due to the efficiency of the process, and the relatively large proportion of forested areas in the catchment. With only $2.4 \%$ of snowfall, ground condensation contribution is the smallest. At the local scale, interpolated precipitation, as well as modelled snowmelt and sublimation during wind-induced snow transport are important water balance quantities, whereas the importance 
Table 2. Contributions relative to total snowfall and scale-dependent significance of the winter water balance components as modelled with AMUNDSEN for the Berchtesgaden National Park domain for 2003/2004. The additional amount of snowmelt is caused by rain-on-snow.

\begin{tabular}{|c|c|c|c|c|}
\hline Water balance component & Seasonal amount (mm) & Relative contribution (\%) & Local significance & Regional significance \\
\hline Snowfall & +651.1 & +100.0 & high & high \\
\hline Ground resublimation & +15.8 & +2.4 & moderate & small \\
\hline Ground sublimation & -44.9 & -6.9 & moderate & small \\
\hline Canopy sublimation & -84.9 & -13.0 & moderate & moderate \\
\hline Sublimation from turbulent suspension & -26.5 & -4.1 & high & small \\
\hline Snowmelt & -693.1 & -106.5 & high & high \\
\hline
\end{tabular}

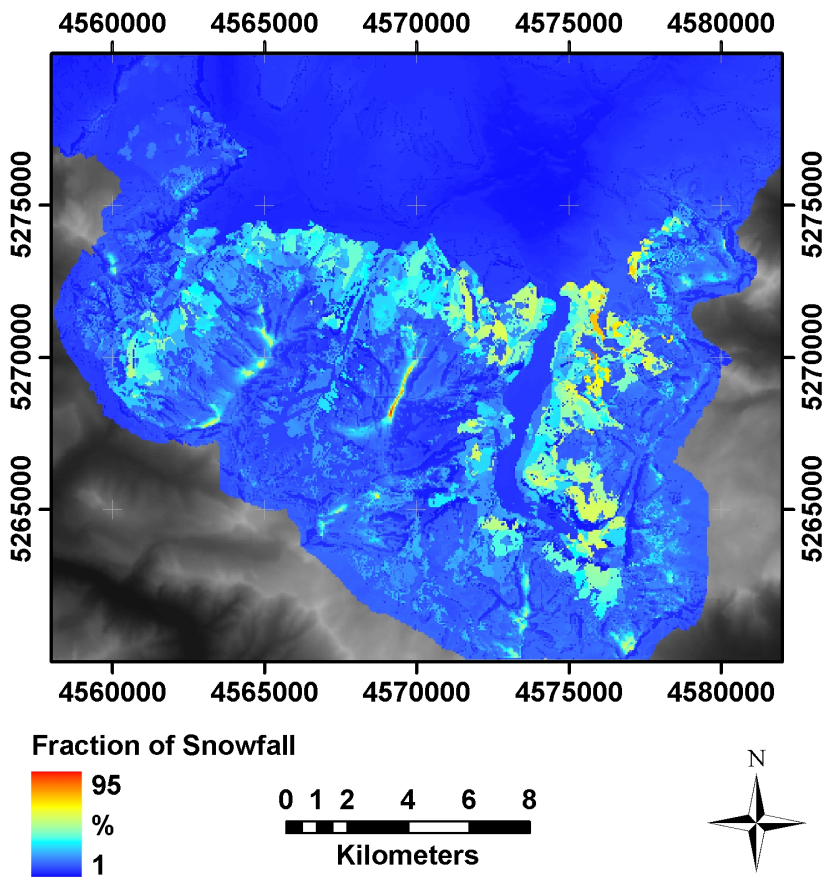

Fig. 15. Fraction of modelled total winterly snow sublimation losses of total winterly snowfall precipitation in the National Park area (2003/2004).

of condensation and sublimation of snow at the ground and from the canopy is moderate. At the regional scale, precipitation and snowmelt still represent important water balance quantities, whereas the contributions of sublimation from the canopy are moderate, while the ones of condensation and sublimation of snow at the ground as well as from windinduced snow transport are small. Lateral redistribution of snow does not affect the water balance of the entire snow storage system, but locally the amount of snow affected may be highly significant.

\section{Conclusions}

We applied the combined, physically based models AMUNDSEN and SnowTran-3D to simulate snow sublima- tion from the ground, from the forest canopy, and from turbulent suspension during wind-induced snow transport in a high mountain region. Our results indicate the seasonal pattern of accumulated snow sublimation is highly variable, with the contributions from ground being spatially relatively homogeneous and adding to about $100 \mathrm{~mm}$ of SWE. This process is most efficient where the snow cover duration is long and wind speeds are generally high, i.e. in the upper regions of the test site. Sublimation from canopy-intercepted snow is most efficient in stands characterized by high trees or in very dense stands, and periods with frequent snowfall events. Results indicate total SWE losses in the range of $100 \mathrm{~mm}$, but in very dense stands with exceptional high LAI almost $300 \mathrm{~mm}$ of SWE is transported back into the atmosphere, but the spatial extent of such canopy types is limited. Most efficient is sublimation from turbulent transport during blowing-snow events: on the most exposed mountain ridges, accumulated sublimation losses add up to more than $1000 \mathrm{~mm}$ of SWE, due to the long duration of snow availability and efficient turbulence at the frequent high wind speed situations. The total fraction of these sublimation losses from winter precipitation is between 10 and $90 \%$. This amount of precipitation is not stored as snow on the ground, and does not contribute to later melt.

We can conclude that snow sublimation does have a significant effect on the alpine water balance, notably in areas where wind-induced snow transport is frequent and efficient. However, these areas are spatially relatively limited. Since the topography of our test site can be regarded as relatively extreme, our results can be interpreted as upper limits, at least for alpine measures. In the valley regions the effect of snow sublimation from the ground and from the canopies is moderate; there, our results are in accordance with the literature (Hood et al., 1999; Marks et al., 1992; Kattelmann und Elder, 1991; Kaser, 1983).

Important aspects arise if the presented model algorithms are included as part of water balance modelling. Generally, in high mountain areas the precipitation inputs are considered to be the most inaccurate quantity, particularly for snowfall which is extremely difficult to measure. Considering our snow sublimation estimates, the usually assumed precipitation underestimation in the measurements is even larger by 
the respective sublimation amount. If the relevant water exchange processes between the snow surface and the atmosphere can be accurately calculated, atmospheric precipitation distributions could be estimated with an inverse modelling approach (e.g., Liston and Sturm, 2002): for that purpose, we are intending to couple our snow processes models with a runoff scheme, and compare simulated streamflow with observations.

Finally, the processes modelled here are important with respect to understanding the long-term snow cover dynamics in high mountain regions under the influence of changing climatic conditions: the high sublimation losses from turbulent suspension at mountain crests are limited to comparably small areas and may not affect alpine water balances significantly. However, if not considered in long-term simulations, snow can accumulate unrealistically in areas where melting processes are relatively inefficient or limited in their seasonal duration. Additionally, the consideration of gravitational snow transport is required for consistently accounting for the removal of snow from higher ridge crests and depositing it in the transition zones at the foot of mountain slopes. In that respect, snow sublimation processes and transport by slides is a prerequisite for obtaining realistic results in the simulated snow cover patterns, and for an adequate representation of accumulation and ablation in the long-term modelling of high mountain snow cover and glacier response to climate change.

Acknowledgements. We are thankful to all who provided their help and assistance for writing the manuscript of this paper, in particular Helmut Franz, Volkmar Konnert and Michael Vogel from the National Park Administration (Berchtesgaden) for data processing and subsidizing our activities. We also acknowledge the contributions of the team of Park rangers for their technical support and valuable expertise for the field work. The meteorological data were generously supplied by the Administration of Salzburg (Untersberg), the Administration Union of the BerchtesgadenKoenigssee region (Schoenau) and the Bavarian Avalanche Warning Center of the State Office for Environment in Munich (Jenner, Reiter Alm, Kuehroint and Funtenseetauern). Michael Warscher (Munich) set up the database for automatically collecting and distributing the meteorological records. The development of AMUNDSEN has profited from the valuable contributions of Monika Prasch (Munich), Javier Corripio (Innsbruck) and Stephan Gruber (Zurich). A significant part of the grants with which this work was facilitated has been provided by the GLOWA-Danube project (http://www.glowa-danube.de/).

Edited by: M. Van den Broeke

\section{References}

Bernhardt, M., Zängl, G., Liston, G. E., Strasser, U., and Mauser, W.: Using wind fields from a high resolution atmospheric model for simulating snow dynamics in mountainous terrain, Hydrol. Process., 27, in press, 2008a.
Bruland, O., Liston, G. E., Vonk, J., Sand, K., and Killingtveit, A.: Modelling the snow distribution at two high arctic sites at Svalbard, Norway, and at an Alpine site in central Norway, Nord. Hydrol., 35, 191-208, 2004.

Burlando, P., Pellicciotti, F., and Strasser, U.: Modelling Mountainous Water Systems Between Learning and Speculating, Looking for Challenges, Nord. Hydrol., 33(1), 47-74, 2002.

Chen, J. M., Rich, P. M., Gower, S. T., Norman, J. M., and Plummer, S.: Leaf area index of boreal forests: Theory, techniques, and measurements, J. Geophys. Res., 102, 29 429-29443, 1997.

Cionco, R. M.: Analysis of canopy index value for various canopy densities, Bound.-Lay. Meteorol., 15, 81-93, 1978.

Corripio, J.: Vectorial algebra algorithms for calculating terrain parameters from DEMs and solar radiation modelling in mountainous terrain, Int. J. Geogr. Inf. Sci., 17(1), 1-23, 2003.

Durot, K.: Modélisation hydrologique distribuée du bassin versant nivo-pluvial de Sarennes. Validation des données d'entrée et dévelopement d'un module de fonte nivale sous forêt, Ph.D. dissertation, LTHE, Grenoble, 332 pp., 1999.

Foken, T.: Angewandte Meteorologie - Mikrometeorologische Methoden, Springer Verlag, ISBN 3540003223, 289 pp., Berlin, 2003.

Greene, E. M., Liston, G. E., and Pielke, R. A.: Simulation of above treeline snowdrift formation using a numerical snow-transport model, Cold Reg. Sci. Tech., 30, 135-144, 1999.

Grell, G. A., Dudhia, J., and Stauffer, D. R.: Tech. Note NCAR/TN398+STR, Boulder, Colorado, 1995.

Greuell, W., Knap, W., and Smeets, P.: Elevational changes in meteorological variables along a midlatitude glacier during summer, J. Geophys. Res., 102(22), 25 941-25 954, 1997.

Gruber, S.: A mass-conserving fast algorithm to parameterize gravitational transport and deposition using digital elevation models, Water Resour. Res., 43, W06412, doi:10.1029/2006WR004868, 2007.

Hammel, K. and Kennel, M.: Charakterisierung und Analyse der Wasserverfügbarkeit und des Wasserhaushaltes von Waldstandorten in Bayern mit dem Simulationsmodell BROOK90, Forstliche Forschungsberichte München, 185, 148 pp., 2001.

Hasholt, B., Liston, G. E., and Knudsen, N. T.: Snow-distribution modelling in the Ammassalik region, south east Greenland, Nord. Hydrol., 34, 1-16, 2003.

Hiemstra, C. A., Liston, G. E., and Reiners, W. A.: Snow redistribution by wind and interactions with vegetation at upper treeline in the Medicine Bow Mountains, Wyoming, USA, Arct., Antarct. Alp. Res., 34, 262-273, 2002.

Hiemstra, C. A., Liston, G. E., and Reiners, W. A.: Observing, modelling, and validating snow redistribution by wind in a Wyoming upper treeline landscape, Ecol. Mod., 197, 35-51, 2006.

Hood, E., Williams, M., and Cline, D.: Sublimation from a seasonal snowpack at a continental, mid-latitude alpine site, Hydrol. Process., 13, 1781-1797, 1999.

Kattelmann, R. and Elder, K.: Hydrologic characteristics and water balance of an alpine basin in the Sierra Nevada, Water Resour. Res., 27, 1553-1562, 1991.

Kaser, G.: Über die Verdunstung auf dem Hintereisferner, Ztschr. f. Gletschk. Glazialgeol., 19(2), 149-162, 1983.

Konnert, V.: Standortkarte Nationalpark Berchtesgaden. Forschungsbericht, 49, Nationalpark Berchtesgaden, Berchtesgaden, 151 pp., 2004. 
Kuchment, L. S. and Gelfan, A. N.: The determination of the snowmelt rate and the meltwater outflow from a snowpack for modelling river runoff generation, J. Hydrol., 179, 23-36, 1996.

Lang, H.: Is evaporation an important component in high alpine hydrology?, Nord. Hydrol., 12, 217-224, 1981.

Lee, L. W.: Sublimation of snow in a turbulent atmosphere, Ph.D. dissertation, University of Wyoming, 162 pp., 1975.

Link, T. and Marks, D.: Point simulation of seasonal snow cover dynamics beneath boreal forest canopies, J. Geophys. Res, 104(22), $27841-27$ 857, 1999.

Liston, G. E. and Sturm, M.: A snow-transport model for complex terrain, J. Hydromet., 3, 646-659, 1998.

Liston, G. E., and Sturm, M.: Winter precipitation patterns in Arctic Alaska Determined from a Blowing-Snow Model and SnowDepth Observations, Nord. Hydrol., 35, 325-334, 2002.

Liston, G. E. and Elder, K.: A Distributed Snow-Evolution Modeling System (SnowModel), J. Hydromet., 7(2), 217-234, 2006.

Liston, G. E., Winther, J. G., Bruland, O., Elvehoy, H., Sand, K., and Karlof, L.: Snow and blue-ice distribution patterns on the coastal Antarctic Ice Sheet, Antarc. Sci., 12, 69-79, 2000.

Liston, G. E., Haehnel, R. B., Sturm, M., Hiemstra, C. A., Berezovskaya, S., and Tabler, R. D.: Simulating complex snow distributions in windy environments using SnowTran-3D, J. Glaciol., 53(181), 241-256, 2007.

Marks, D., Dozier, J., and Davis, R. E.: Climate and energy exchange at the snow surface in the alpine region of the Sierra Nevada: 1. Meteorological measurements and monitoring, Water Resour. Res., 17, 609-627, 1992.

Marsh, P.: Snowcover formation and melt: recent advances and future prospects, Hydrol. Process., 13, 2117-2134, 1999.

Montesi, J., Elder, K., Schmidt, R. A., and Davis, R. E.: Sublimation of intercepted snow within a subalpine forest canopy at two elevations, J. Hydromet., 5, 763-773, 2004.

Obled, Ch.: Modèle mathématique de la fusion nivale, Ph.D. dissertation, Institut de mécanique de Grenoble, Grenoble, 170 pp., 1971.

Pellicciotti, F., Brock, B., Strasser, U., Burlando, P., Funk, M., and Corripio, J.: An enhanced temperature-index glacier melt model including shortwave radiation balance: development and testing for Haut Glacier d'Arolla, Switzerland, J. Glaciol., 51(175), 573-587, 2005.

Pomeroy, J. W. and Gray, D. M.: Snowcover: Accumulation, Relocation, and Management. National Hydrology Research Institute, Saskatoon, Canada, NHRI Science Report, 7, Saskatoon, 144 pp., 1995.

Pomeroy, J. W. and Dion, K.: Winter radiation extinction and refection in a boreal pine canopy: measurements and modelling, Hydrol. Process., 10, 1591-1608, 1996.

Pomeroy, J. W. and Essery, R. L. H.: Turbulent fluxes during blowing snow: field test of model sublimation prediction, Hydrol. Process., 13, 2963-2975, 1999.

Pomeroy, J. W., Gray, D.M., and Landine, P. G.: The Prairie Blowing Snow Model - characteristics, validation, operation, J. Hydrol., 144, 165-192, 1993.

Pomeroy, J. W., Gray, D. M., Shook, K. R., Toth, B., Essery, R. L. H., Pietroniero, A., and Hedstrom, N.: An evaluation of snow accumulation and ablation for land surface modelling, Hydrol. Process., 12, 2339-2367, 1998.

Pomeroy, J. W., Gray, D. M., Hedstrom, N., and Janowicz, J. R.:
Prediction of seasonal snow accumulation in cold climate forests, Hydrol. Process., 16, 3543-3558, 2002.

Prasad, R., Tarboton, D. G., Liston, G. E., Luce, C. H., and Seyfried, M. S.: Testing a blowing snow model against distributed snow measurements at Upper Sheep Creek, Idaho, United States of America, Water Resour. Res., 37, 1341-1356, 2001.

Prasch, M., Strasser, U., and Mauser, W.: Validation of a physically based snow model for the simulation of the accumulation and ablation of snow (ESCIMO), in: Proceedings of the Alpine*Snow*Workshop (www.alpinesnowworkshop.org), edited by: Strasser, U. and Vogel, M., Munich, October 5-6, 2006, Germany, Berchtesgaden National Park research report, 53, 2007

Rohrer, M. B.: Die Schneedecke im Schweizer Alpenraum und ihre Modellierung, Zuer. Geogr. Schriften, 49, 178 pp., 1992.

Sovilla, B.: Field experiments and numerical modelling of mass entrainment and deposition in snow avalanches, Ph.D. dissertation, ETH Zurich, Switzerland, 2004.

Strasser, U. and Mauser, W.: Modelling the Spatial and Temporal Variations of the Water Balance for the Weser Catchment 19651994, J. Hydrol., 254(1-4), 199-214, 2001.

Strasser, U. and Etchevers, P.: Simulation of Daily Discharges for the Upper Durance Catchment (French Alps) Using Subgrid Parameterization for Topography and a Forest Canopy Climate Model, Hydrol. Process., 19, 2361-2373, 2005.

Strasser, U., Etchevers, P., and Lejeune, Y.: Intercomparision of two Snow Models with Different Complexity Using Data from an Alpine Site, Nord. Hydrol., 33(1), 15-26, 2002.

Strasser, U., Corripio, J., Brock, B., Pellicciotti, F., Burlando, P. and Funk, M.: Spatial and Temporal Variability of Meteorological Variables at Haut Glacier d'Arolla (Switzerland) During the Ablation Season 2001: Measurements and Simulations, J. Geophys. Res., 109(3), D03103, doi:10.1029/2003JD003973, 2004.

Strasser, U., Franz, H., and Mauser, W.: Distributed modelling of snow processes in the Berchtesgaden National Park (Germany), in: Proceedings of the Alpine*Snow*Workshop (www. alpinesnowworkshop.org), edited by: Strasser, U. and Vogel, M., Munich, October 5-6, 2006, Germany, Berchtesgaden National Park research report, 52, 2008.

Suzuki, K. and Nakai, Y.: Canopy snow influence on water and energy balances in a coniferous forest plantation in northern Japan, J. Hydrol., 352, 126-138, 2008

Tribbeck, M. J., Gurney, R., Morris, E. M., and Pearson, D. W. C.: A new Snow-SVAT to simulate the accumulation and ablation of seasonal snow beneath a forest canopy, J. Glaciol., 50(169), 171-182, 2004.

US Army Corps of Engineers: Snow Hydrology, US Army Corps of Engineers, North Pacific Division, Portland, 437 pp., 1956.

Weber, M.: A parameterization for the turbulent fluxes over melting surfaces derived from eddy correlation measurements, in: Proceedings of the Alpine*Snow*Workshop (www. alpinesnowworkshop.org), edited by: Strasser, U. and Vogel, M. Munich, October 5-6, 2006, Germany, Berchtesgaden National Park research report, Nr. 53, 2007.

Zappa, M., Pos, F., Strasser, U., Warmerdam, P., and Gurtz, J.: Seasonal water balance of an Alpine catchment as evaluated by different methods for spatially distributed snowmelt modelling, Nord. Hydrol., 34(3), 179-202, 2003. 